\title{
LncRNA-mediated regulation of SOX9 expression in basal subtype breast cancer cells
}

\author{
AAMIRA TARIQ, ${ }^{1,2}$ QINYU HAO, ${ }^{2}$ QINYU SUN,${ }^{2}$ DEEPAK K. SINGH, ${ }^{2}$ MAHDIEH JADALIHA, ${ }^{2}$ YANG ZHANG, $^{3}$ \\ NEHA CHETLANGIA, ${ }^{2}$ JIAN MA, ${ }^{3}$ SARAH E. HOLTON, ${ }^{4}$ ROHIT BHARGAVA, ${ }^{4}$ ASHISH LAL, ${ }^{5}$ \\ SUPRIYA G. PRASANTH, ${ }^{2}$ and KANNANGANATTU V. PRASANTH ${ }^{2}$ \\ ${ }^{1}$ Department of Biosciences, Comsats Institute of Information Technology, Islamabad 45550, Pakistan \\ ${ }^{2}$ Department of Cell and Developmental Biology, Cancer Center at Illinois, University of Illinois at Urbana-Champaign, Urbana, Illinois 61801, USA \\ ${ }^{3}$ Computational Biology Department, School of Computer Science, Carnegie Mellon University, Pittsburgh, Pennsylvania 15213, USA \\ ${ }^{4}$ Department of Bioengineering and Beckman Institute of Advanced Science and Technology, Cancer Center at Illinois, University of Illinois at \\ Urbana-Champaign, Urbana, Illinois 61801, USA \\ ${ }^{5}$ Regulatory RNAs and Cancer Section, Genetics Branch, Center for Cancer Research, National Cancer Institute, National Institutes of Health, \\ Bethesda, Maryland 20892, USA
}

\begin{abstract}
Triple-negative breast cancer (TNBC) is one of the most aggressive breast cancer (BC) subtypes with a poor prognosis and high recurrence rate. Recent studies have identified vital roles played by several IncRNAs (long noncoding RNAs) in BC pathobiology. Cell type-specific expression of IncRNAs and their potential role in regulating the expression of oncogenic and tumor suppressor genes have made them promising cancer drug targets. By performing a transcriptome screen in an isogenic TNBC/basal subtype BC progression cell line model, we recently reported 1800 IncRNAs that display aberrant expression during breast cancer progression. Mechanistic studies on one such nuclear-retained IncRNA, linc02095, reveal that it promotes breast cancer proliferation by facilitating the expression of oncogenic transcription factor, SOX9. Both linc02095 and SOX9 display coregulated expression in BC patients as well in basal subtype BC cell lines. Knockdown of linc02095 results in decreased BC cell proliferation, whereas its overexpression promotes cells proliferation. Linc02095-depleted cells display reduced expression of SOX9 concomitant with reduced RNA polymerase II occupancy at the SOX9 gene body as well as defective SOX9 mRNA export, implying that linc02095 positively regulates SOX9 transcription and mRNA export. Finally, we identify a positive feedback loop in BC cells that controls the expression of both linc02095 and SOX9. Thus, our results unearth tumor-promoting activities of a nuclear IncRNA linc02095 by facilitating the expression of key oncogenic transcription factor in $\mathrm{BC}$.
\end{abstract}

Keywords: nuclear IncRNA; basal-like subtype; TNBC; regulation; enhancer

\section{INTRODUCTION}

Breast cancer $(\mathrm{BC})$ is a frequently diagnosed malignancy and a leading cause of death among women across the globe (Siegel et al. 2016). Breast cancer, like most other epithelial tumors, is a heterogeneous disease with diverse subtypes (Nguyen and Massagué 2007). These subtypes differ from each other in clinical behavior, therapeutic response profiles, and the presence or absence of receptors such as estrogen receptor (ER), progesterone receptor (PR), and human epidermal growth factor 2 (HER2). Based on expression of these receptors, $B C$ is classified into different categories: luminal A (ER+, PR+, and HER2-), luminal B

Corresponding authors: aamira_tariq@comsats.edu.pk, kumarp@ illinois.edu

Article is online at http://www.rnajournal.org/cgi/doi/10.1261/rna. 073254.119.
(ER+, PR+, and HER2+/-), HER2-positive (ER-, PR-, and HER2-), and triple negative BC (ER-, PR-, and HER2-) (Weigelt et al. 2010; Jadaliha et al. 2016).

Triple negative breast cancer (TNBC) has been further classified into two distinct molecular subtypes; basal-like and claudin-low, based on their unique gene expression profiles (Jadaliha et al. 2016). There are no targeted therapies available for TNBC, and patients are typically treated with chemotherapy. However, TNBC patients display poor outcomes due to disease heterogeneity and chemotherapy resistance (Lv et al. 2016).

(C) 2020 Tariq et al. This article is distributed exclusively by the RNA Society for the first 12 months after the full-issue publication date (see http://rnajournal.cshlp.org/site/misc/terms.xhtml). After 12 months, it is available under a Creative Commons License (Attribution-NonCommercial 4.0 International), as described at http:// creativecommons.org/licenses/by-nc/4.0/. 
Less than $2 \%$ of the human genome encodes proteins; $\sim 75 \%$ of the human genome encodes noncoding RNAs that are: transcripts with no apparent protein-coding potential, such as microRNAs (miRNAs), piwi-interacting RNAs (piRNAs), and the least understood long noncoding RNAs (IncRNAs) (Prensner and Chinnaiyan 2011). In general, IncRNAs range in size between $\sim 200 \mathrm{bp}$ to $100 \mathrm{~kb}$ (Derrien et al. 2012). Genome-wide transcriptome analysis revealed that the human genome harbors $>16,000$ IncRNA genes (https://www.gencodegenes.org/human/ stats.html) (Jalali et al. 2016). Mechanistic studies on a handful of them revealed that IncRNAs along with their interacting protein partners contribute toward the regulation of diverse biological processes, including cell proliferation (Prensner and Chinnaiyan 2011; Ulitsky and Bartel 2013; Schmitt and Chang 2016). They achieve this by modulating gene expression via different molecular mechanisms such as chromatin modification, transcription, protein activity and localization, and posttranscriptional gene regulation (Xu et al. 2017). In the context of $B C$, recent studies have identified several hundreds of IncRNAs as plausible prognostic markers of BC (Van Grembergen et al. 2016). The aberrant expression of IncRNAs like CCAT2 (Cai et al. 2015), MALAT1 (Jin et al. 2016), H19 (Matouk et al. 2014), HOTAIR (Gupta et al. 2010), and ZFAS1 (Hansji et al. 2016) has been associated with BC metastasis. Moreover, tissue type- and cell type-specific expression of IncRNAs have made them promising candidates to address $\mathrm{BC}$ cancer cell heterogeneity (Cabili et al. 2011).

In the present study, we investigated the potential role of a TNBC up-regulated IncRNA, linc02095, in BC cell proliferation. We observed elevated expression of both linc02095 and its neighboring protein-coding gene SOX9 in TNBC patient samples. Gain- and loss-of-function experiments revealed that linc02095 promotes cell proliferation and $\mathrm{BC}$ progression in vitro. Furthermore, we found that both linc02095 and SOX9 regulated the expression of each other, and this coregulation is required for enhanced tumorigenic activities of BC cells. Taken together, our results imply that linc02095 could function as an oncogenic IncRNA in BC via its role in promoting the expression of oncogenic and prometastatic transcription factor SOX9.

\section{RESULTS}

\section{Linc02095 is up-regulated in TNBC BC cells and patient samples}

Human breast carcinoma could progress via sequential genetic modifications of benign hyperplasia of mammary duct epithelial cells into atypical ductal hyperplasia, to ductal carcinoma in situ, to invasive tumor localized to the breast or lymph node, ultimately metastasizing to distant organs (Santner et al. 2001). In order to understand the role of IncRNAs during BC progression, we utilized a wellestablished isogenic mammary epithelial cell line-derived triple negative breast cancer (TNBC or basal subtype) progression model system. This model system consists of three isogenic cell lines (M1, M3, and M4), all of them originally derived from nontumorigenic MCF10A mammary epithelial cells. The cell line series consist of MCF10A (M1), tumorigenic but less metastatic MCF10CA1h (M3) and highly tumorigenic and metastatic MCF10CA1a.c11 (M4) cells. M3 gives predominantly well-differentiated low-grade carcinomas in the xeno-graft models (Tang et al. 2003; Imbalzano et al. 2009; Kadota et al. 2009, 2010; Fu et al. 2010; McKeen Polizzotti et al. 2012).

We recently performed poly $A^{+}$deep RNA-seq ( 160250 million paired-end reads/sample) of $M 1, M 2, M 3$, and M4 cells that were grown as three-dimensional (3D) acinar or organoid-like structures in Matrigel for 7-10 d (Jadaliha et al. 2018). By analyzing the RNA-seq, $>1800$ IncRNAs were deregulated at least twofold in tumorigenic M3 cells compared to the nontumorigenic M1 cells (Jadaliha et al. 2018). Several of IncRNAs that showed altered expression between M1 versus M3 cells also displayed aberrant expression in BC patient samples (Jadaliha et al. 2018). In the present study, we focused on one such IncRNA, linc02095 or ROCR (Regulator of chondrogeneis) (Barter et al. 2017) (ENSG00000228639.2/AC005152.3) that was consistently elevated in M3 cells as compared to M1 cells (Supplemental Fig. S1A). Linc02095 is a multiexonic gene located on chromosome 17q23 and is transcribed into multiple transcript isoforms of (624 and 323 nt long) (Supplemental Fig. S1A,B). Our RNA-seq data revealed that all the isoforms of linc02095 showed elevated levels in M3 cells (Supplemental Fig. S1A,B). Quantitative realtime PCR (RT-qPCR) analysis confirmed significantly elevated linc02095 levels in M3 (>100-fold) cells (Fig. 1A). RTqPCR results revealed that linc02095 also displayed enhanced expression even in 2D grown M4 cells (greater than fivefold) over M1 cells (Fig. 1A). RT-qPCR from nuclear and cytoplasmic fractionated RNA revealed that linc02095 was preferentially localized in the nuclear fraction (Fig. 1B), similar to the well-established nuclear IncRNA, MALAT1 (Tripathi et al. 2012, 2013). In addition, linc02095 was found to be a poly $\mathrm{A}^{+}$RNA (Fig. 1C). Interestingly, the gene encoding the stem cell transcription factor SOX9 is located in close proximity to the linc02095 locus ( 95 $\mathrm{kb}$ ) and is transcribed in the opposite direction (see Supplemental Fig. S1C). Several IncRNAs show coregulated expression with protein-coding genes located in genomic proximity, and some of them also regulate the expression of protein-coding genes in a cis-regulated manner (Schmitt and Chang 2016; Warburton and Boone 2017; Yan et al. 2017). We therefore sought to determine whether SOX9 also displayed coregulated expression with linc02095 in the M1 and M3 cells. Both RNA-seq and RT-qPCR data 


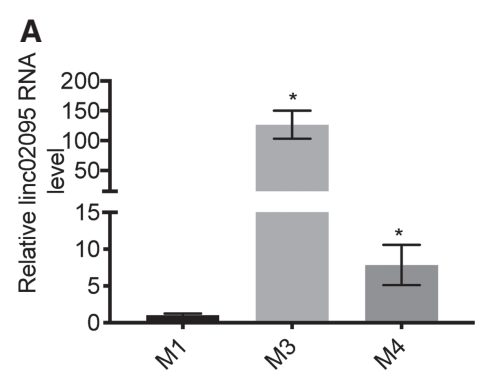

B

C
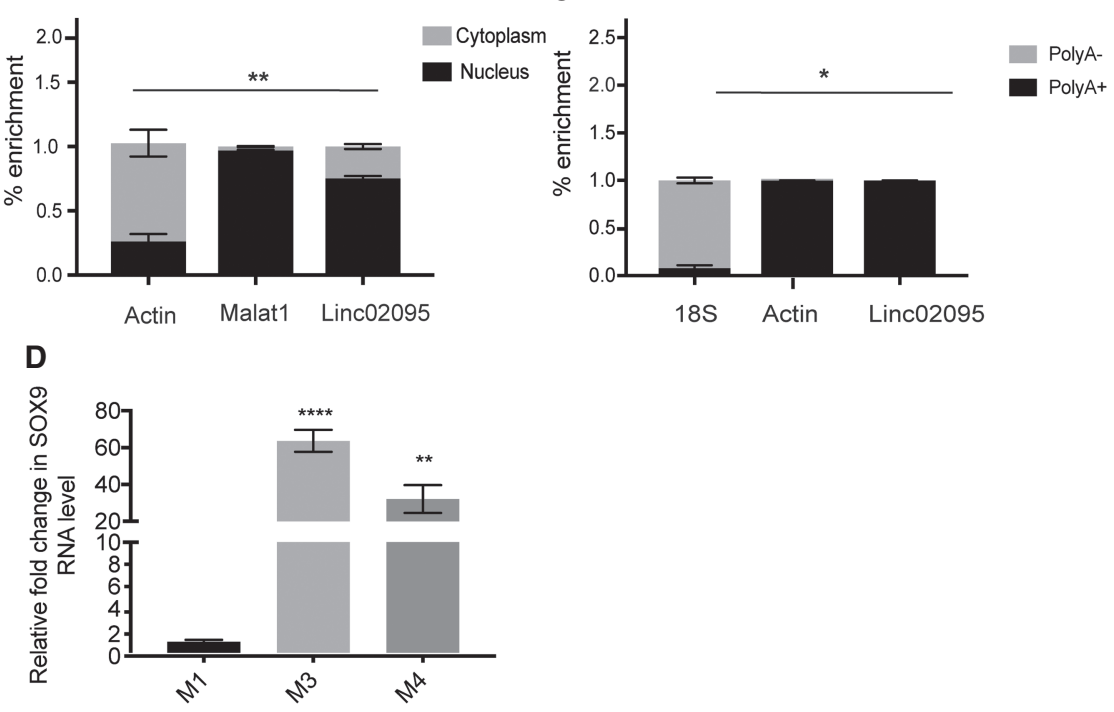

FIGURE 1. Nuclear-enriched and polyadenylated linc02095 show elevated expression in BC cells. (A) RT-qPCR showing relatively high levels of linc02095 in M3, as compared to M1 and M4 cells. (B) RT-qPCR in nuclear and cytoplasmic fractionated cell extracts showing relative localization of linc02095, MALAT1, and actin RNA. MALAT1 (nuclear) and Actin (cytoplasm) are used as controls. (C) RT-qPCR analyses in poly(A) ${ }^{+}$and poly $(A)^{-}$fractionated $M 3$ cells. 18SrRNA [poly $(A)^{-}$] and actin [poly $(A)^{+}$] were used as controls. (D) RT-qPCR showing relative levels of SOX9 mRNA in $\mathrm{M} 1$ and $\mathrm{M} 3$ cells. Error bars in $A-D$ represent $\pm \mathrm{SD}$ of three independent experiments, that is, biological replicates. $P$-values, $\left(^{*}\right) P<0.05$, $\left.{ }^{(* *}\right) P<0.01$, were obtained by using Student's $t$-test.

demonstrated that SOX9 showed enhanced expression in M3 cells compared to M1 cells (Fig. 1D; Supplemental Fig. S1C). Similar to linc02095, SOX9 also showed elevated levels in M4 cells over M1 (Fig. 1D). Further, immunofluorescence staining of SOX9 in M3 cells revealed that it preferentially enriched in the nucleus in all of the cells (Supplemental Fig. S2). Earlier studies had reported that SOX9 is up-regulated in BC samples, and SOX9 plays an essential role in the induction and maintenance of tumor-initiating capacity of BC cells (Fazilaty et al. 2016; Jeselsohn et al. 2017). We therefore analyzed whether linc02095 also showed elevated expression in BC patient samples of various subtypes using TANRIC (The Atlas of Noncoding RNA In Cancer) (Li et al. 2015a) CRN (Cancer RNA-Seq Nexus)-based analyses of the TCGA data set (Li et al. 2015b). Both linc02095 and SOX9 showed significantly elevated levels in basal subtype (TNBC) BC samples as compared to other BC subtypes (Supplemental Fig. S3A-E). Our results imply that both linc02095 and SOX9 show elevated expression in TNBC or basal-like cell line and in patient samples.

\section{Linc02095 and SOX9 coregulate the expression of each other}

To determine whether linc02095 positively regulates the expression of SOX9, we performed linc02095 loss-of-function studies. By stably expressing two independent shRNAs (sh1-02095 and sh3-02095) targeting linc02095, we suc- cessfully depleted linc02095 in M3 cells (Fig. 2A). M3 cells depleted of linc02095 showed a significant decrease in the levels of SOX9 mRNA (Fig. 2B). Further, immunoblotting showed that linc02095-depletion resulted in a significant decrease in SOX9 protein (Fig. 2C). To test whether linc02095 positively regulates the expression of other genes located in SOX9 locus neighborhood, we determined the levels of several other IncRNA transcripts (SOX9-AS1, linc001152, linc00511) that are located near the SOX9 gene locus (Supplemental Fig. S4A) in control and linc02095-depleted cells. Our RNA-seq revealed that SOX-AS1 also showed elevated expression in M3 cells over M1 (Supplemental Fig. S4B) whereas linc001152, and linc00511 showed low expression in M1 and M3 cells (Supplemental Fig. S4C,D). However, linc02095 depletion in $\mathrm{M} 3$ cells resulted in enhanced expression of both SOX9AS1 and linc001152 (Supplemental Fig. S4E). On the contrary, linc00511 showed no significant change in the levels upon linc02095 depletion (Supplemental Fig. S4E). On the contrary, SOX9 KD led to a decrease on SOX9AS1 level indicating that SOX9 might regulate SOX9-AS1 expression (Supplemental Fig. S4F). These results imply that linc02095 could positively or negatively regulate the expression of specific genes in the SOX9 gene neighborhood. The up-regulation of SOX9-AS1 upon linc02095 depletion raised the possibility that linc02095 may regulate the expression of SOX9 via modulating SOX9-AS1 expression. To test this model, we determined the levels of SOX9 mRNA in the absence of SOX9-AS1. 
A

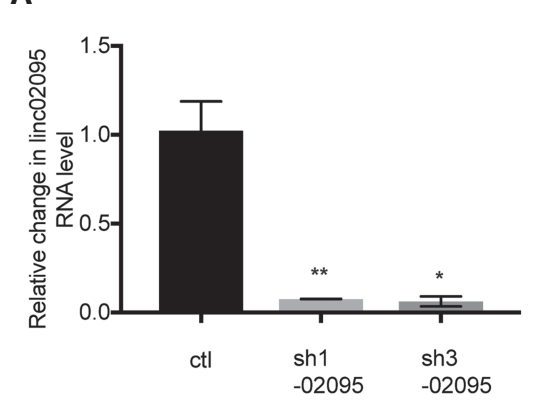

B

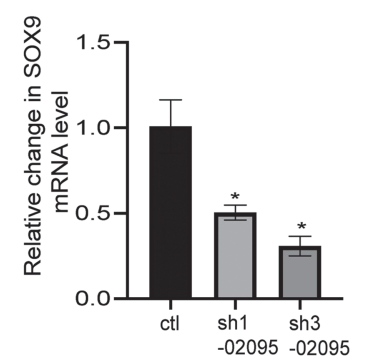

C
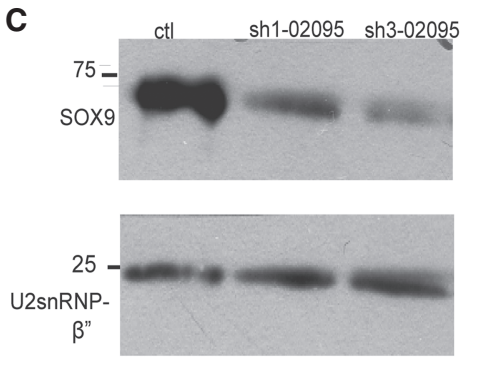

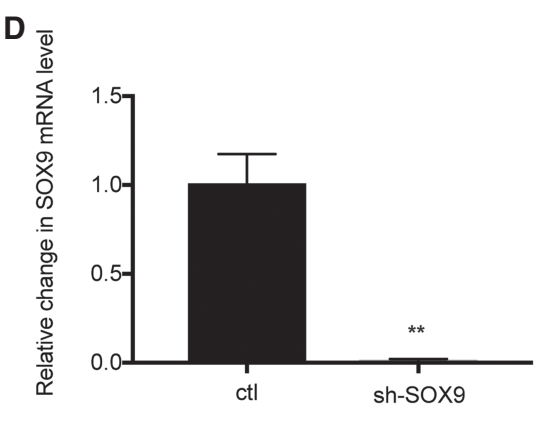

E

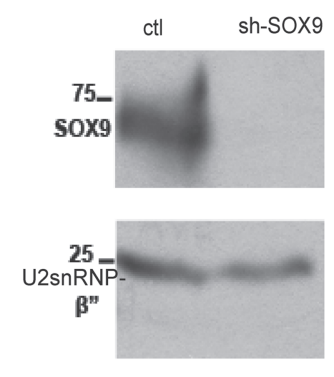

$\mathbf{F}$

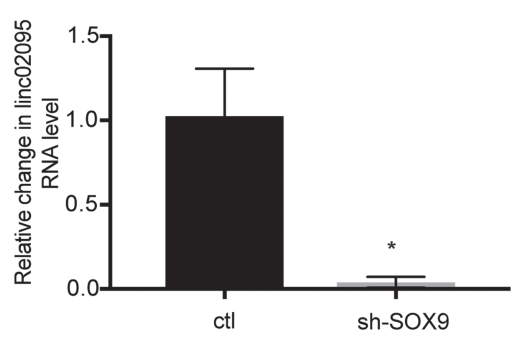

FIGURE 2. Linc02095 and SOX9 coregulated the expression of each other. (A) RT-qPCR showing relative levels of linc02095 in control and linc02095-specific shRNA-treated (sh1-02095 and sh3-02095) M3 cells. (B,C) RT-qPCR and immunoblot showing relative levels of SOX9 mRNA and protein in control and linc02095-depleted M3 cells. (D,E) RT-qPCR and immunoblot showing relative levels of SOX9 mRNA and protein in control and SOX9-specific ShRNA (sh-SOX9)transduced M3 cells. $(F)$ RT-qPCR showing relative levels of linc02095 in M3 cells depleted of SOX9. Data $(A, B, D, F)$ represent mean $\pm S D$ of three independent experiments. $P$-values, $\left({ }^{*}\right) P<0.05,\left({ }^{* *}\right) P<0.01$, were obtained by using Student's t-test.

SOX9-AS1 KD caused a small but significant increase in SOX9 mRNA level, indicating that it negatively regulates SOX9 expression (Supplemental Fig. S4G). However, both control and SOX9-AS1-depleted M3 cells that were devoid of linc02095 continued to show low levels of SOX9 mRNA (Supplemental Fig. S4G), implying that SOX9-AS1 depletion could not rescue the levels of SOX9 in linc02095-depleted cells. These results suggest that linc02095 regulates the expression of SOX9 and SOX9AS1 via independent mechanisms. On the other hand, SOX9-AS1 KD could act as a negative regulator of SOX9. Next, we determined whether SOX9 regulates the expression of linc02095 or SOX9-AS1. M3 cells stably depleted of SOX9 (sh-SOX9) showed reduced levels of both SOX9 mRNA and SOX9 protein (Fig. 2D,E). Interestingly, depletion of SOX9 led to a decrease in linc02095 and SOX9-
AS1 RNA levels (Fig. 2F; Supplemental Fig. S4F). Thus, our results indicated that both linc02095 and SOX9 positively regulate the expression of each other in $\mathrm{BC}$ cells.

\section{SOX9 and linc02095 promote cell proliferation in TNBC cells}

Earlier studies have documented the involvement of SOX9 in breast tumor cell proliferation (Fazilaty et al. 2016; Lei et al. 2016). Since linc02095 positively regulated SOX9 expression in $B C$ cells, we determined the involvement of linc02095 in cell proliferation. Long-term cell proliferation assessed by anchorage-dependent growth assay revealed that depletion of either linc02095 or SOX9 significantly inhibited cell proliferation (Fig. 3Ai,ii, $\mathrm{Bi}, \mathrm{ii})$. Furthermore, BrdU-PI flow cytometry analyses revealed that linc02095-depleted cells showed defective S-phase progression (Supplemental Fig. S5A). Next, we transiently overexpressed one of the isoforms of linc02095 (323 nt) in M3 cells and determined the effect on cell proliferation. Colony formation assays revealed that linc02095-overexpressing cells showed enhanced cell proliferation (Fig. 3Ci-iii). Linc02095overexpressing cells also showed enhanced levels of SOX9 mRNA (Fig. 3Civ). SOX9 has been implicated in the formation and growth of tumors in various tissues, including breast (Fazilaty et al. 2016; Jeselsohn et al. 2017). We tested the ability of linc02095 and SOX9 to control the tumorigenicity of BC cells by performing anchorage-independent soft-agar colony formation assays. We observed that depletion of linc02095 or SOX9 reduced anchorage-independent growth of M3 cells as observed by the reduced number of colonies, implying that linc02095 and SOX9 promote clonogenicity in vitro (Supplemental Fig. S5B,C). Defects in cell proliferation and tumorigenicity upon linc02095 depletion could be attributed to changes in the expression of genes controlling the cell cycle. RT-qPCR studies confirmed that linc02095depleted cells show reduced expression of several oncogenes (Aurora kinase, Bub1b, cyclin A and Cenp E), controlling cell cycle progression (Fig. 3E). Based on these results, we conclude that linc02095 promotes cell proliferation and tumor progression in BC, potentially by 

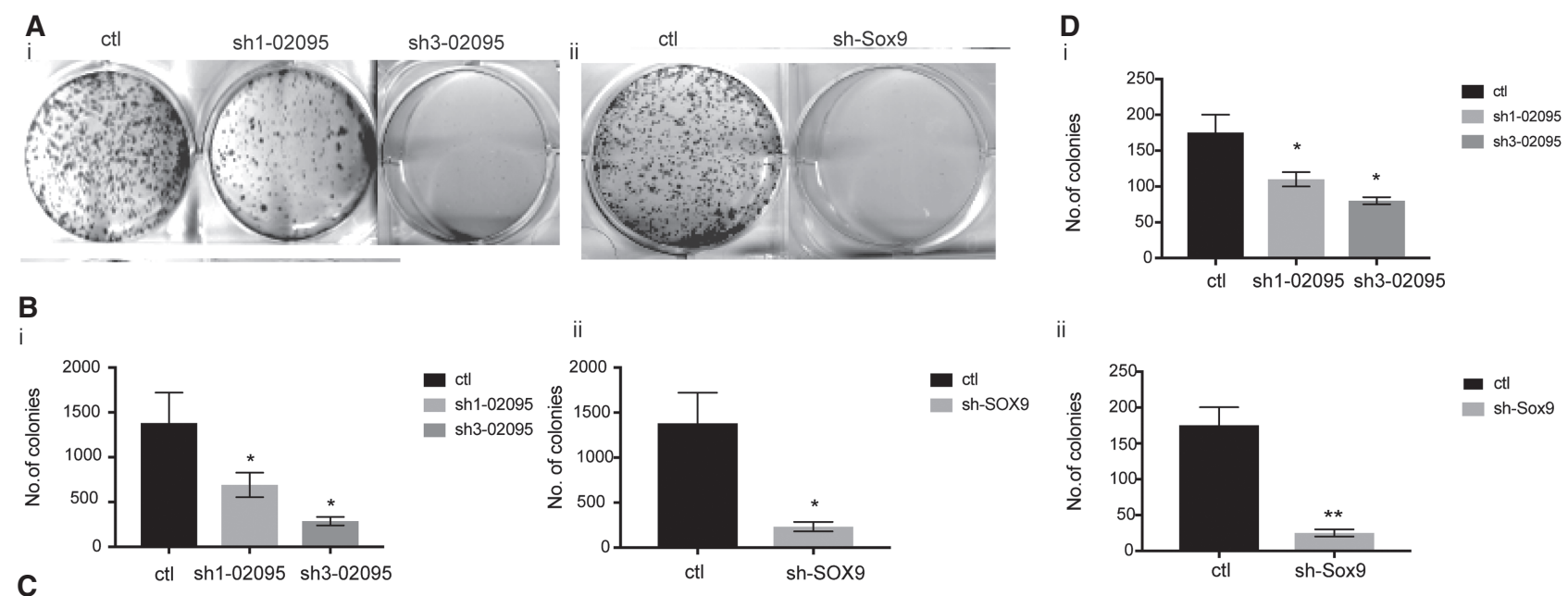

ii
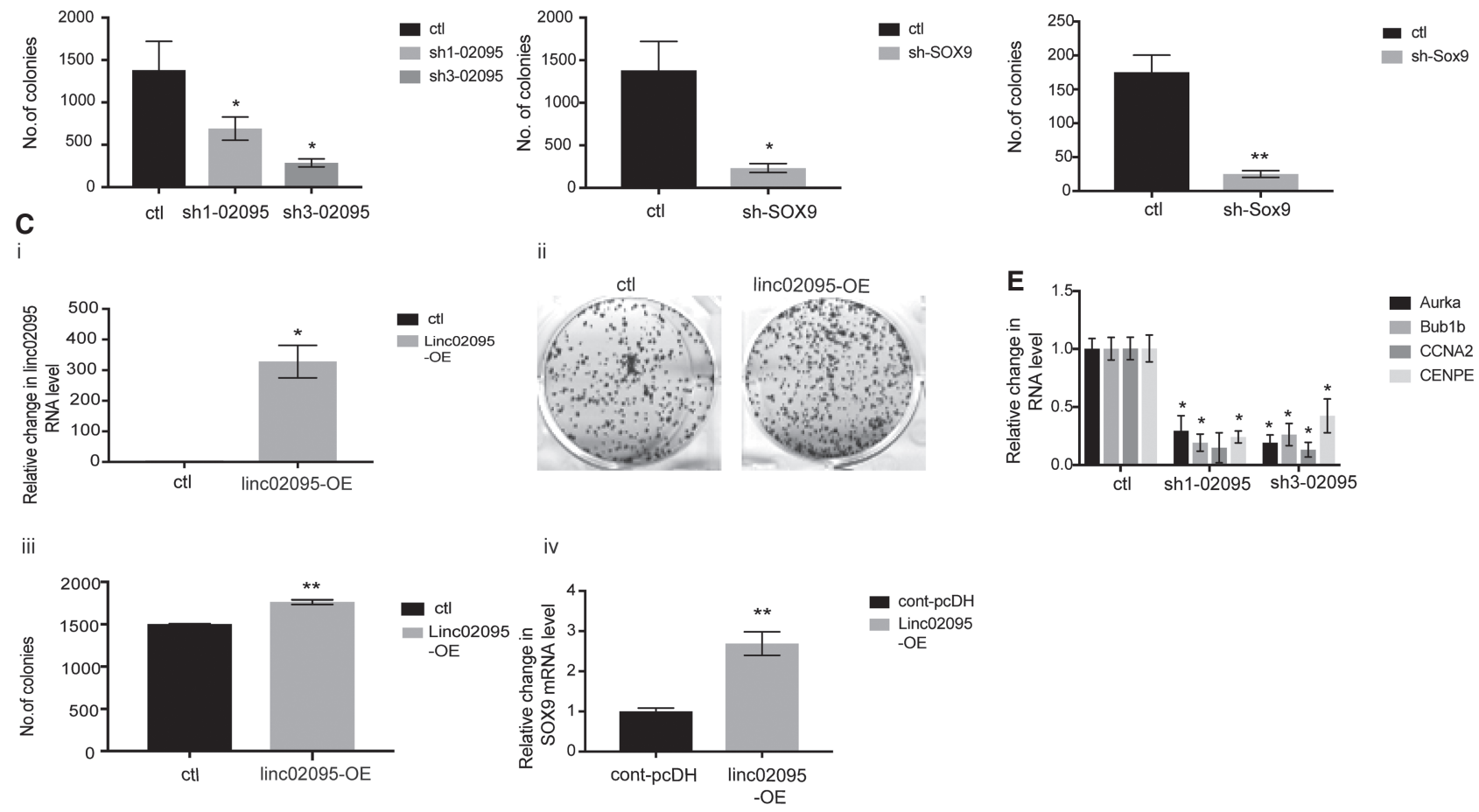

FIGURE 3. Linc02095 and SOX9 promoted cell proliferation in BC cells. $(A, i, i i)$. Plastic colony assay showing reduced colony numbers in cells depleted of linc02095 and SOX9. (B,a,b) Quantification of the data presented in A. (C,i) RT-qPCR showing relative levels of linc02095 in cells overexpressing linc02095. (C,ii) Plastic colony assay showing increased cell proliferation upon linc02095 overexpression. (C,iii) Quantification of data presented in $\mathrm{Cb}$. ( $C$,iv) RT-qPCR showing increased SOX9 mRNA levels in linc02095 overexpressed cells. $(D, a, b)$ Anchorage independent growth assay showing reduced number of colonies in linc02095 and SOX9 depleted cells. (E) RT-qPCR to show relative expression of several cell cycle genes in linc02095-depleted cells. Error bars in $B(i, i i), C(i, i i i, i v), D(i, i i)$, and $E$ represent $\pm S D$ of three independent experiments, that is, biological replicates. $P$-values, $\left(^{*}\right) P<0.05,\left(^{* *}\right) P<0.01$, were obtained by using Student's $t$-test.

influencing the expression of genes controlling cell cycle progression.

\section{Linc02095 modulates SOX9 expression}

To further elucidate the mechanism by which linc02095 might regulate SOX9 expression, we determined the status of RNA pol II occupancy on the SOX9 promoter and gene body by performing RNA polymerase II (Pol II) ChIP in control and linc02095-depleted cells. Linc02095-depleted cells showed decreased enrichment of RNA Pol II at the promoter and gene body of SOX9 gene (Fig. 4A). On the other hand, Pol II displayed no significant difference in association to b-actin promoter in control and linc02095-depleted cells. Our data illustrate that knock down of linc02095 affects SOX9 expression at the transcription level. We next determined whether linc02095depletion has any impact on the chromatin organization at the SOX9 regulatory region such as the promoter. Toward this, we determined potential changes in H3K4me3 modification, an epigenetic mark present at the $5^{\prime}$ end of the gene surrounding the transcription start site (TSS) (Barski et al. 2007), at the SOX9 promoter upon linc02095 depletion. ChiP-qPCR did not show any significant change in $\mathrm{H} 3 \mathrm{~K} 4 \mathrm{me} 3$ occupancy at the SOX9 promoter in the presence or absence of linc02095 (Fig. 4B). Based on this, we conclude that linc02095 modulates SOX9 transcription, potentially by altering the loading or elongation of RNA polymerase II, without having an impact on the chromatin structure. 
A

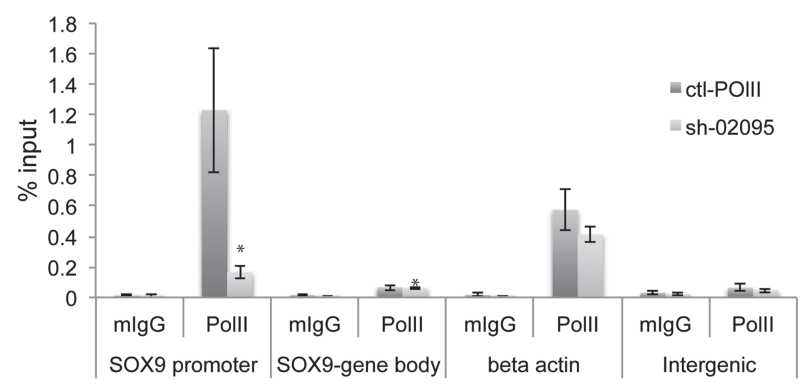

B

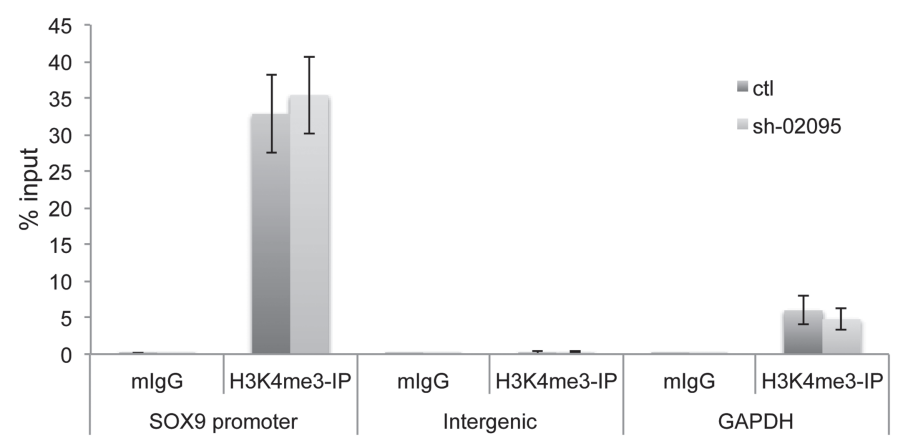

C

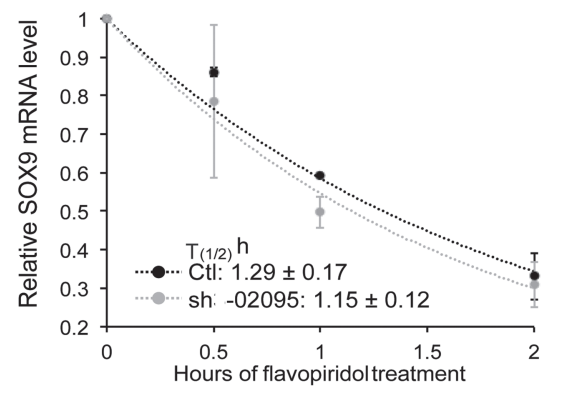

D

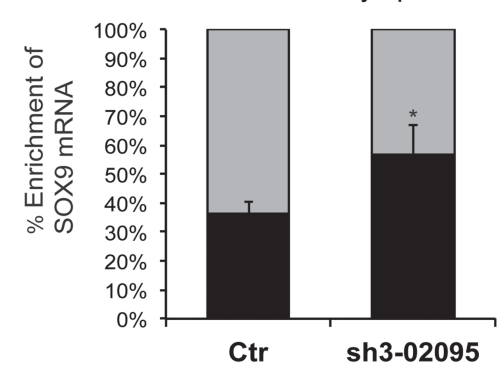

FIGURE 4. SOX9 facilitates the transcription of linc02095. (A) RNA polymerase II chip showing reduced association of RNA polymerase $\|$ at the promoter and gene body of SOX9 in linc02095-depleted M3 cells. B-actin and Ch17NC are used as positive and negative controls, respectively. (B) $\mathrm{H} 3 \mathrm{~K} 4 \mathrm{me} 3$ chip showing no significant change in its association to the SOX9 promoter in control and linc02095 depleted cells. (C) RT-qPCR to quantify the stability of SOX9 mRNA in control and linc02095 depleted M3 cells treated with Flavopiridol (1M) for indicated time points $(0,1,2,3 \mathrm{~h})$. (D) Nuclear and cytoplasmic fractionation of control and linc02095 depleted cells showing increased nuclear retention of SOX9 transcript in the absence of linc02095. Error bars in A-D represent $\pm S D$ of three independent experiments, that is, biological replicates. $P$-values, $\left(^{*}\right) P<0.05,\left(^{* *}\right) P<0.01$, were obtained by using Student's t-test.

Besides transcription, IncRNAs are also known to regulate posttranscriptional events, including RNA stability and export. We next determined whether linc02095 modulates RNA stability and export of SOX9 mRNA. We treated control and linc02095-depleted M3 cells with RNA Pol II transcription inhibitor Falvopiridol $(1 \mu \mathrm{M})$ for indicated time points, and determined the turnover rate (half-life) of SOX9 mRNA. Our data illustrated that knock down of linc02095 did not impact the turn-over rate of SOX9 mRNA (Fig. 4C; $t_{1 / 2} 1.15 \pm 0.12$ as opposed to control $1.29 \pm 0.17)$. To test whether linc02095 influenced the lo- calization of SOX9 mRNA, we performed RT-qPCR analyses of nuclear and cytoplasmic RNA fractions from control and linc02095-depleted cells. Interestingly, linc02095-depleted cells showed a significant reduction in the cytoplasmic pool of SOX9 mRNA compared to control cells (Fig. 4D). The reduction in the cytoplasmic pool of SOX9 mRNA could contribute to lower levels of SOX9 protein in linc02095-depleted M3 cells. These results indicate that linc02095 regulates SOX9 transcription and export of the SOX9 mRNA. Future studies will focus on determining the precise molecular mechanism by which linc02095 regulates the SOX9 expression.

\section{SOX9 promotes the expression of linc02095}

The significant decrease in linc02095 mRNA levels in SOX9-depleted cells further intrigued us to test the possibility of a positive-feedback mechanism. To assess whether SOX9 induces the transcription of linc02095, we looked for SOX9 binding motifs in the linc02095 promoter region. We found two consensus SOX9 binding motifs in the promoter region of linc02095 (CCAAT, ACAAAG; highlighted in blue boxes) (Fig. 5A-C; Shi et al. 2015). SOX9 recognizes specific promoter regulatory elements by forming heterodimeric complexes with other transcription factors, including SOX6 (Liu and Lefebvre 2015) and SOX6 (Ohba et al. 2015). We also found consensus SOX6 and RUNX1 motifs in the promoter region of linc02095 (Fig. $5 \mathrm{~A}$; highlighted in green and red). To examine the binding of SOX9 to the linc02095 promoter, we performed SOX9 ChIP-qPCR on the linc02095 promoter region in M1 (cell expressing low levels of SOX9 and linc02095) and M3 (cell type expressing elevated levels of SOX9 and linc02095) cells (Fig. 5D; Supplemental Fig. S6). We found significant enrichment of SOX9 at the linc02095 promoter in $\mathrm{M} 3$ as compared to $\mathrm{M} 1$ cells (Fig. 5D). Other known SOX9 target genes, including S100P (highly expressed in M3) and CCNB1 (highly expressed in M1) were used as a positive control; a noncoding region from chromosome 


\section{A}

tcagaaaaggagccaaggaatagtgttagacaccacttcagatttatccaatataatatttacaaagtggtgget ttttttcttagtgtaagttttaatctattggtattagcaatatctgcttttctcctgccttgctttacacagatt catgattttctaaaaactgatgttttactcaaattgaggtaggttctttctactgtcttacataactttgggtg catagaccaagattatttatacactgtagaagtcgatggtattaaatccgctcaagaagtaagagaagtcagagg ctaagtcacgaaaacctttgtcaaaagactgtagggtgaatgtggtttttgcatccaaagctttacctgtgggt ctaatatagattctgtgcattcatcttctgcagggaccatttcagtag

B
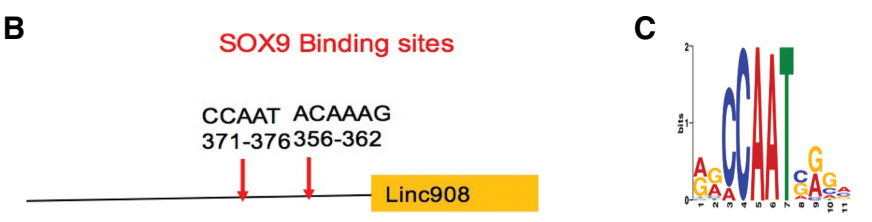

D

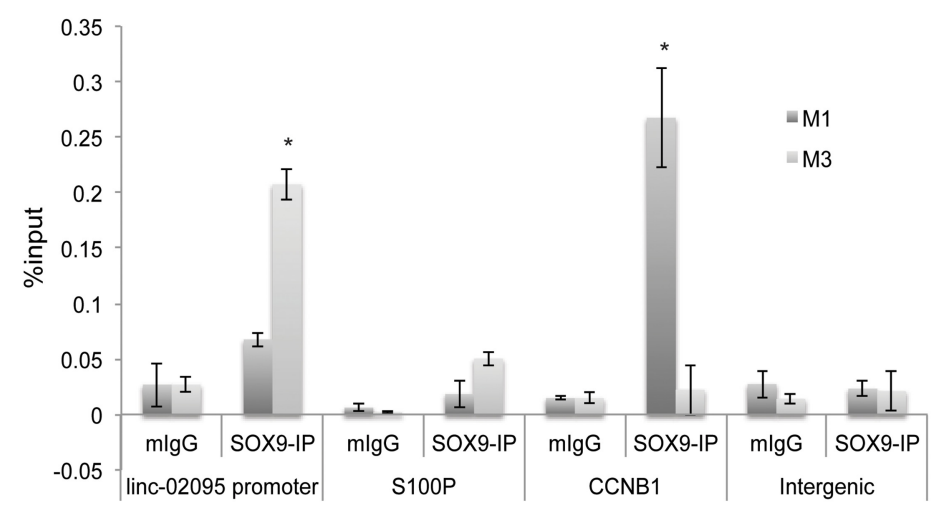

FIGURE 5. SOX9 facilitates the transcription of linc02095. (A) Promoter sequence of linc02095, showing potential consensus binding sites of SOX9 (highlighted in blue), SOX6 (highlighted in green), RUNX1 (highlighted in red) and 5' end of transcript (highlighted in yellow). (B) Genomic position of SOX9 binding sites of linc02095 promoter. (C) Consensus SOX9 binding motifs, based on previous literature (Shi et al. 2015). (D) OPCR followed by SOX9 ChIP in $\mathrm{M} 1$ and $\mathrm{M} 3$ cells. Please note the increased association of SOX9 in the promoter region of linc02095 and S100P in M3 cells. S100P and CCNB1 were used as positive controls. The noncoding region from chromosome 17 was used as a negative control showing no binding of SOX9. SOX9 showed binding to linc02095 promoter in M3 cells as opposed to M1 cells. Data $(D)$ represent mean \pm SD of three independent experiments. $P$-value, $\left(^{*}\right) P<0.05$, was obtained by using Student's t-test.

17 was used as a negative control to rule out nonspecific binding of SOX9 (Fig. 5D). In summary, we demonstrated significant enrichment of SOX9 at the promoter of linc02095, coregulated expression of linc02095 and SOX9 in BC cells, and reduced expression of linc02095 in SOX9-depleted cells. Based on these results, we conclude that SOX9 is a bona fide transcription activator of linc02095. Additionally, linc02095 and SOX9 positively regulate each other's expression in $\mathrm{BC}$ cells as part of a positive feedback mechanism in order to promote cell proliferation and tumor progression.

\section{Linc02095 rescues cell proliferation defects observed in SOX9-depleted cells}

We further investigated whether linc02095 acts as a driver of SOX9 expression. We exogenously overexpressed

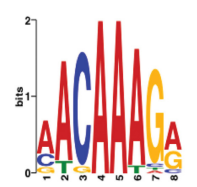

linc02095 in BC cells stably depleted of endogenous SOX9 and determined the effect on SOX9 expression and cell proliferation (Fig. 6A; Supplemental Fig. S7). Linc02095 overexpressed cells showed consistent increase in the levels of SOX9 mRNA and SOX9 protein (Fig. 6B,C). At present, it is not clear how transient overexpression of linc02095 resulted in enhanced levels of SOX9. Linc02095 could potentially enhance SOX9 transcription in trans or SOX9 mRNA export to the cytoplasm ensuring their translation leading to an increase in protein levels (Fig. 6B,C). Alternatively, elevated expression of SOX9 could result in enhanced cell proliferation upon linc02095 OE. We observed that linc02095 overexpressing cells rescued the cell proliferation defects observed upon SOX9 depletion (Fig. 6D,E), implying that linc02095 promotes BC cell proliferation.

\section{DISCUSSION}

In the present study, we observed elevated expression of linc02095 in basal BC cells. High expression of linc02095 in tumorigenic cells reflects its potential as a regulator of cell proliferation and tumor progression in basal-like BC cells (Supplemental Fig. S3). Moreover, we also found that linc02095 positively regulates the expression of SOX9 both at transcriptional and posttranscriptional levels. In support of our observation, a very recent study reported that depletion of ROCR or linc02095 in mesenchymal stem cells (MSC) disrupted MSC chondrogenesis by decreasing SOX9 expression (Barter et al. 2017). Together, these results indicated that linc02095 regulated the expression of SOX9 in different cell or tissue types under physiological and pathological conditions.

The SOX9 gene is located at $17 q 23$ in a gene desert $\sim 2 \mathrm{Mb}$ region surrounded by several IncRNA genes. SOX9 is an HMG-box transcription factor that plays an essential role in several cellular processes, including lineage specification and chondrocyte development (Akiyama 2008; Pritchett et al. 2011). Several enhancer elements have been identified, which are located upstream of SOX9 gene $(-70,-84,-195$, and $-250 \mathrm{~kb})$, and these enhancer elements control tissue or cell type-specific 


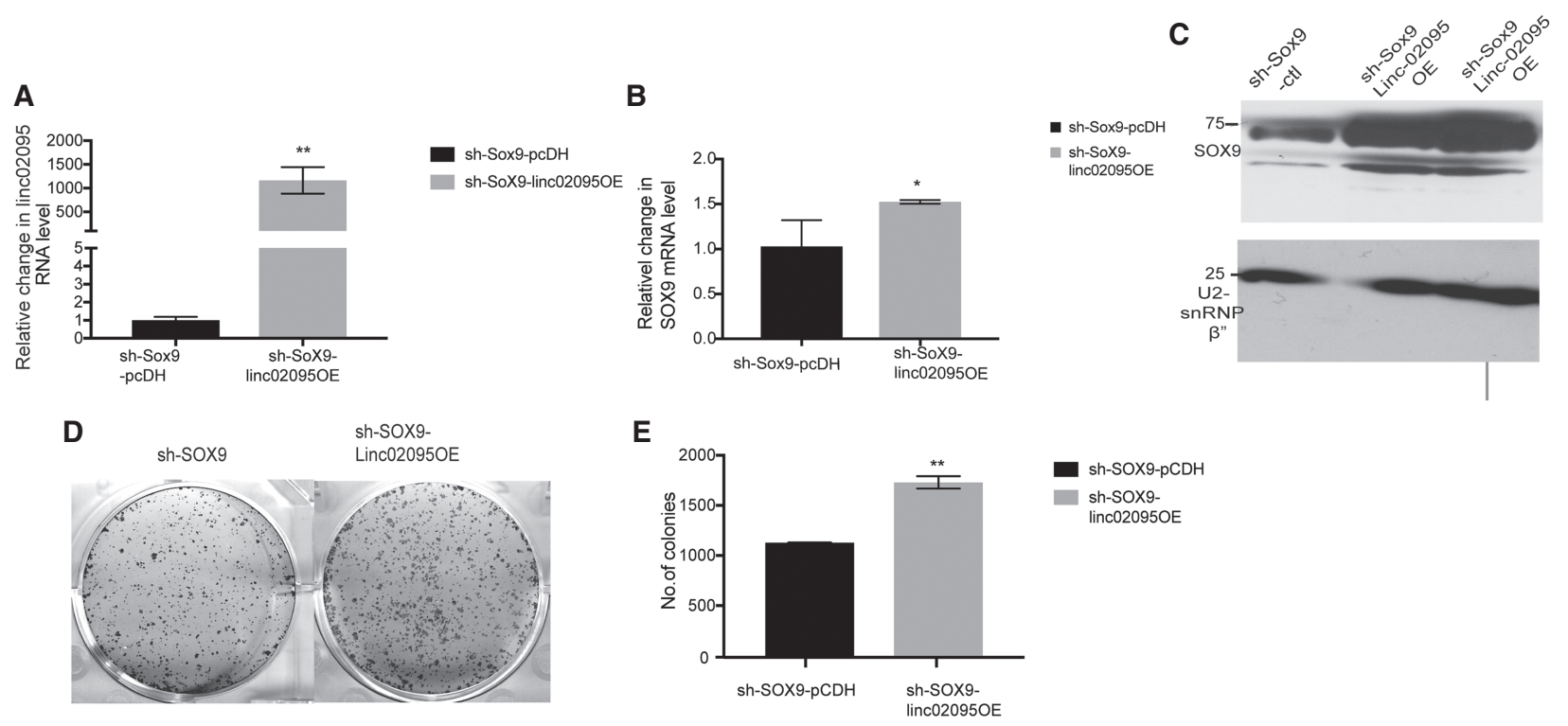

FIGURE 6. Overexpression of linc02095 increases the cellular levels of SOX9 and promotes cell proliferation. (A) RT-qPCR showing increased levels of linc02095 in SOX9-depleted M3 cells overexpressing linc02095. $(B, C)$ RT-qPCR and immunoblot showing rescue of endogenous SOX9 in SOX9-depleted M3 cells overexpressing linc02095. $(D, E)$ Plastic colony assay showing increased cell proliferation in linc02095 overexpressed M3 cells depleted of endogenous SOX9. Error bars in $A, B, E$ represent \pm SD of three independent experiments, that is, biological replicates. $P$-values, $(*) P<0.05,(* *) P<0.01$, were obtained by using Student's $t$-test.

expression of SOX9 (Leipoldt et al. 2007; Gordon et al. 2009; Mead et al. 2013; Yao et al. 2015). Furthermore, chromosome conformation capture-on-chip (4C) analysis in testicular Sertoli cells and peripheral lymphoblasts revealed potential interaction between SOX9 promoter region and the flanking upstream (Smyk et al. 2013) and downstream enhancer elements as a consequence of chromatin looping (Gordon et al. 2009; Smyk et al. 2013; Yao et al. 2015). Chromosomal rearrangements with breakpoints mapping up to $1.6 \mathrm{Mb}$ up- or downstream from SOX9 have been identified in patients with campomelic dysplasia (CD), a skeletal malformation syndrome often associated with sex reversal (Leipoldt et al. 2007). This suggests that aberrant activation of one or more of these enhancers could contribute to altered expression of $\mathrm{SOX} 9$ and disease pathology. An earlier study reported that several regulatory elements of SOX9 also overlap with IncRNA genes. Linc02095 is transcribed from one of the enhancer regions, located $\sim 95 \mathrm{~kb}$ upstream of SOX9 gene (Supplemental Fig. S1). A recent bioinformatics study reported a positive correlation between SOX9 and linc02095 expression (AC005152.3 or $R O C R$; $R$-value 0.42 ) in basal $B C$ samples further supporting our observation that both linc02095 and SOX9 are coregulated in BC (Supplemental Fig. S8; Su et al. 2014; Tang et al. 2017). Our knockdown experiments demonstrated that linc02095 plays a functional role in regulating SOX9 expression thereby modulating cell proliferation. SOX9 displays strong nuclear localization in TNBC cells as opposed to other BC subtypes (Pomp et al. 2015). Furthermore, the nuclear localization of linc02095 (Fig.
1C) and the enrichment of H3K4me1 and H3K27Ac marks across linc02095 gene body (Supplemental Fig. S9) raised the possibility that linc02095 could act as an enhancer RNA. Our RNA Pol II Chip analyses further support the model that linc02095 promotes SOX9 transcription. Linc02095KD leads to an increase in nuclear localization of SOX9 mRNA. Such nuclear retention of SOX9 mRNA could also result in reduced levels of SOX9 protein. Based on the results, we propose that linc02095 is one of several regulatory IncRNAs that are transcribed from SOX9 regulatory elements and is involved in promoting the expression of SOX9 in TNBC cells. The genomic positioning of linc02095 at the SOX9 enhancer region and its up-regulation in basal $\mathrm{BC}$ reflects a potential interplay of these candidates in regulating $\mathrm{BC}$ progression.

\section{MATERIALS AND METHODS}

\section{Cell culture}

The benign and nontumorigenic MCF10A (M1) cells were cultured in DMEM/F12 medium containing $5 \%$ horse serum supplemented with $100 \mathrm{U} / \mathrm{mL}$ penicillin, $100 \mu \mathrm{g} / \mathrm{mL}$ streptomycin, $20 \mathrm{ng} / \mathrm{mL}$ EGF (epidermal growth factor), $0.5 \mu \mathrm{g} / \mathrm{mL}$ Hydrocortisone, $100 \mathrm{ng} / \mathrm{mL}$ Cholera toxin, $10 \mu \mathrm{g} / \mathrm{mL}$ insulin and $5 \%$ horse serum. M3 (MCF10CA1h) and M4 (MCF10CA1a.cl1) cells are Hras transformed MCF10A cells derivatives, which were isolated from tumors followed by xenografting for several generations. M3 cells possess high tumorigenicity with low metastatic potential (Dawson et al. 1996). M4 (MCF10CA1a.cl1) cells tend to 
be highly tumorigenic and metastatic in nature. M3 and M4 cells were cultured DMEM/F12 medium containing 5\% horse serum supplemented with $100 \mathrm{U} / \mathrm{mL}$ penicillin, $100 \mu \mathrm{g} / \mathrm{mL}$ streptomycin.

\section{Cell fractionation}

The nuclear and cytoplasmic fractionation was performed as described previously (Anantharaman et al. 2016, 2017). Briefly, M3 cells were cultured for $36 \mathrm{~h}$ to reach $80 \%$ confluence. Cells were initially washed with ice cold phosphate buffer saline (PBS) and lyzed in the RSB buffer $(10 \mathrm{mM}$ Tris- $\mathrm{HCl} \mathrm{pH} 7.4,100 \mathrm{mM} \mathrm{NaCl}$, $2.5 \mathrm{mM} \mathrm{MgCl}_{2}$, RNase Inhibitor, Digitonin $(8 \mu \mathrm{g} / \mathrm{mL})$ on ice. The supernatant (cytoplasmic fraction) was collected after centrifugation (2000 rpm, $4^{\circ} \mathrm{C}, 10 \mathrm{~min}$ ). The pellet (nuclear fraction) was washed with RSB buffer as described above. The nuclear RNA and cytoplasmic RNA were extracted by using TRIzol LS and TRIzol reagent, respectively (Invitrogen). $C_{t}$ values of the nuclear or cytoplasmic fraction were normalized to the total RNA.

\section{RNA extraction and RT-qPCR analysis}

Total RNA was extracted with Tri-reagent (Sigma) followed by DNase I digestion (Sigma). One microgram of total RNA was reverse transcribed into cDNA using M-MLV reverse transcriptase (Promega). Quantitative RT-PCR was performed using the Step One Plus system. (Applied Biosystems) and primers used are listed in Supplemental Table S1. The relative fold change in mRNA level was determined by using the $2^{-\Delta \Delta C T}$ method (Livak and Schmittgen 2001).

\section{Linc02095 knockdown/overexpression experiments}

Linc02095 and SOX9 were stably depleted in BC cells using lentiviral-mediated transduction of shRNAs followed by puromycin selection (Supplemental Table S2). For overexpression, full-length human linc02095 was expressed using lentivirus-mediated transduction, and stable lines were selected using puromycin selection. Empty vector transduced cells were used as a control.

\section{Soft agar anchorage-independent and anchorage- dependent plastic colony formation assays}

Anchorage-independent colony formation $\left(5 \times 10^{3}\right.$ cells $)$ and plastic colony formation ( $1 \times 10^{3} \mathrm{M} 3$ and $2 \times 10^{3} \mathrm{M} 3$ cells) assays were performed as described previously (Jadaliha et al. 2016, 2018).

\section{Chromatin-immunoprecipitation (ChIP)}

ChIP was performed using the previously published study from our laboratory (Khan et al. 2015). Cells in biological triplicates were cross-linked in $1 \%$ formaldehyde (Sigma) for $10 \mathrm{~min}$ at room temperature, followed by glycine $(0.125 \mathrm{M}$ final concentration) treatment to quench crosslinking. Chromatin was prepared in two subsequent extraction steps $\left(10 \mathrm{~min}\right.$ at $\left.4^{\circ} \mathrm{C}\right)$ with Buffer 1 (50 mM Hepes/KOH pH 7.5; 140 mM NaCl; 1 mM EDTA; 10\% glycerol; $0.5 \%$ NP-40; $0.25 \%$ Triton) and Buffer $2(200 \mathrm{mM}$ $\mathrm{NaCl} ; 1 \mathrm{mM}$ EDTA; $0.5 \mathrm{mM}$ EGTA; $10 \mathrm{mM}$ Tris $\mathrm{pH}$ 8). The nuclei were resuspended in Buffer $3(50 \mathrm{mM}$ Tris $\mathrm{pH} 8 ; 0.1 \%$ SDS; $1 \%$ NP-40; 0.1\% Na-Deoxycholate; 10 mM EDTA; $150 \mathrm{mM} \mathrm{NaCl}$ ). The pellet was then subjected to sonication with Bioruptor Power-up (Diagenode) resulting in the genomic DNA fragments within size range of 150-300 bp. Preclearing of the chromatin was done with Protein A/G ultralink beads $(53,133$, Pierce) for $2 \mathrm{~h}$ at $4^{\circ} \mathrm{C}$. Immunoprecipitation was performed using specific antibodies against RNA polymerase II (Millipore, cat. \# 05-623), H3K9me3 (Millipore 07-523) and SOX9 (Millipore Cat \# AB5535) overnight at $4^{\circ} \mathrm{C}$. Immuno-complexes were recovered by adding preblocked protein G Dynabeads (Life Technologies) and incubated for $2 \mathrm{~h}$ at RT. The unbound DNA fragments were removed by washing the beads twice with low salt buffer $(0.1 \%$ SDS; $1 \%$ Triton; 2 mM EDTA; $20 \mathrm{mM}$ Tris $\mathrm{pH} 8 ; 150 \mathrm{mM} \mathrm{NaCl}$ ) and twice with high salt buffer $(0.1 \%$ SDS; $1 \%$ Triton; $2 \mathrm{mM}$ EDTA; $20 \mathrm{mM}$ Tris $\mathrm{pH} 8 ; 500 \mathrm{mM} \mathrm{NaCl}$ ). The beads were further washed once with $\mathrm{LiCl}$ wash buffer $(10 \mathrm{mM}$ Tris $\mathrm{pH}$ 8.0; $1 \% \mathrm{Na}$ deoxycholate; 1\% NP-40, $250 \mathrm{mM} \mathrm{LiCl} ; 1 \mathrm{mM}$ EDTA), and twice with $\mathrm{TE}+50 \mathrm{mM} \mathrm{NaCl}$. Beads were eluted in TE $+1 \% \mathrm{SDS}$ at $65^{\circ} \mathrm{C}$, and was reverse cross-linked overnight at $65^{\circ} \mathrm{C}$. The eluted DNA was used for QPCR. ChIP primers are detailed in Supplemental Table S2. ChIP-qPCR results were calculated as percentage of IP/input signal (\% input).

\section{Flow cytometry}

Flow cytometric analysis to quantify $S$-phase progression was done by using using BrdU and PI as labels for the control and linc02095 depleted cells, as described previously (Tripathi et al. 2013).

\section{RNA stability assay}

To measure RNA stability, cells were treated with Flavopiridol $(1 \mu \mathrm{M})$ for different durations as indicated. Total RNA was extracted at each of the time points and subjected to RT-qPCR. An exponential curve $\left(y=e^{-b t}\right)$ was then fitted to the data points. The halflife was then calculated using the equation $t_{1 / 2}=\ln 2 / \mathrm{b}$ from each of the experiments. The average half-life with SD is shown in the graph (Fig. 4C).

\section{SUPPLEMENTAL MATERIAL}

Supplemental material is available for this article.

\section{ACKNOWLEDGMENTS}

We thank members of Dr. Prasanth's laboratory for their valuable comments. We thank Dr. Xinying Zong for technical assistance. This work was supported by the National Institutes of Health (National Institute of General Medical Sciences grants GM088252 to K.V.P., GM099669 and GM125196 to S.G.P.); Cancer Center at Illinois seed grant and Prairie Dragon Paddlers to K.V.P., National Science Foundation (EAGER grant to K.V.P. [1723008] and career award [1243372] and 1818286 to S.G.P.). A.L. was supported by the Intramural Research Program of the 
National Cancer Institute (NCI), Center for Cancer Research (CCR). A.T. was supported by a Fulbright fellowship. M.J. was supported by a UIUC dissertation completion fellowship. R.B. was supported by R01EB009745.

Received September 5, 2019; accepted October 30, 2019.

\section{REFERENCES}

Akiyama H. 2008. Control of chondrogenesis by the transcription factor Sox9. Mod Rheumatol 18: 213-219. doi:10.3109/s10165-0080048-x

Anantharaman A, Jadaliha M, Tripathi V, Nakagawa S, Hirose T, Jantsch MF, Prasanth SG, Prasanth KV. 2016. Paraspeckles modulate the intranuclear distribution of paraspeckle-associated Ctn RNA. Sci Rep 6: 34043. doi:10.1038/srep34043

Anantharaman A, Tripathi V, Khan A, Yoon J-H, Singh DK, Gholamalamdari O, Guang S, Ohlson J, Wahlstedt H, Öhman M, et al. 2017. ADAR2 regulates RNA stability by modifying access of decay-promoting RNA-binding proteins. Nucleic Acids Res 45: 4189-4201. doi:10.1093/nar/gkw1304

Barski A, Cuddapah S, Cui K, Roh T-Y, Schones DE, Wang Z, Wei G, Chepelev I, Zhao K. 2007. High-resolution profiling of histone methylations in the human genome. Cell 129: 823-837. doi:10 .1016/j.cell.2007.05.009

Barter MJ, Gomez R, Hyatt S, Cheung K, Skelton AJ, Xu Y, Clark IM, Young DA. 2017. The long non-coding RNA ROCR contributes to SOX9 expression and chondrogenic differentiation of human mesenchymal stem cells. Development 144: 4510-4521. doi:10 $.1242 /$ dev. 152504

Cabili MN, Trapnell C, Goff L, Koziol M, Tazon-Vega B, Regev A, Rinn JL. 2011. Integrative annotation of human large intergenic noncoding RNAs reveals global properties and specific subclasses. Genes Dev 25: 1915-1927. doi:10.1101/gad.17446611

Cai Y, He J, Zhang D. 2015. Long noncoding RNA CCAT2 promotes breast tumor growth by regulating the Wnt signaling pathway. OncoTargets Ther 8: 2657. doi:10.2147/OTT.S90485

Dawson PJ, Wolman SR, Tait L, Heppner GH, Miller FR. 1996. MCF10AT: a model for the evolution of cancer from proliferative breast disease. Am J Pathol 148: 313.

Derrien T, Johnson R, Bussotti G, Tanzer A, Djebali S, Tilgner $H_{\text {, }}$ Guernec G, Martin D, Merkel A, Knowles DG, et al. 2012. The GENCODE v7 catalog of human long noncoding RNAs: analysis of their gene structure, evolution, and expression. Genome Res 22: 1775-1789. doi:10.1101/gr.132159.111

Fazilaty H, Gardaneh M, Akbari P, Zekri A, Behnam B. 2016. SLUG and SOX9 cooperatively regulate tumor initiating niche factors in breast cancer. Cancer Microenviron 9: 71-74. doi:10.1007/ s12307-015-0176-8

Fu J, Weise AM, Falany JL, Falany CN, Thibodeau BJ, Miller FR, Kocarek TA, Runge-Morris M. 2010. Expression of estrogenicity genes in a lineage cell culture model of human breast cancer progression. Breast Cancer Res Treat 120: 35-45. doi:10.1007/ s10549-009-0363-8

Gordon CT, Tan TY, Benko S, Fitzpatrick D, Lyonnet S, Farlie PG. 2009. Long-range regulation at the SOX9 locus in development and disease. J Med Genet 46: 649-656. doi:10.1136/jmg.2009 .068361

Gupta RA, Shah N, Wang KC, Kim J, Horlings HM, Wong DJ, Tsai MC, Hung T, Argani P, Rinn JL, et al. 2010. Long non-coding RNA HOTAIR reprograms chromatin state to promote cancer metastasis. Nature 464: 1071. doi:10.1038/nature08975

Hansji $H$, Leung EY, Baguley BC, Finlay GJ, Cameron-Smith D, Figueiredo VC, Askarian-Amiri ME. 2016. ZFAS1: a long noncod- ing RNA associated with ribosomes in breast cancer cells. Biol Direct 11: 62. doi:10.1186/s13062-016-0165-y

Imbalzano KM, Tatarkova I, Imbalzano AN, Nickerson JA. 2009. Increasingly transformed MCF-10A cells have a progressively tumor-like phenotype in three-dimensional basement membrane culture. Cancer Cell Int 9: 7. doi:10.1186/1475-2867-9-7

Jadaliha M, Zong X, Malakar P, Ray T, Singh DK, Freier SM, Jensen T, Prasanth SG, Karni R, Ray PS, et al. 2016. Functional and prognostic significance of long non-coding RNA MALAT1 as a metastasis driver in ER negative lymph node negative breast cancer. Oncotarget 7: 40418. doi:10.18632/oncotarget.9622

Jadaliha M, Gholamalamdari O, Tang W, Zhang Y, Petracovici A, Hao Q, Tariq A, Kim TG, Holton SE, Singh DK, et al. 2018. A natural antisense IncRNA controls breast cancer progression by promoting tumor suppressor gene mRNA stability. PLoS Genet 14: e1007802. doi:10.1371/journal.pgen.1007802

Jalali S, Gandhi S, Scaria V. 2016. Navigating the dynamic landscape of long noncoding RNA and protein-coding gene annotations in GENCODE. Hum Genomics 10: 35. doi:10.1186/s40246-0160090-2

Jeselsohn R, Cornwell M, Pun M, Buchwalter G, Nguyen M, Bango C, Huang Y, Kuang Y, Paweletz C, Fu X, et al. 2017. Embryonic transcription factor SOX9 drives breast cancer endocrine resistance. Proc Natl Acad Sci 114: E4482-E4491. doi:10.1073/pnas .1620993114

Jin C, Lu Q, Lin Y, Ma L. 2016. Reciprocal regulation of Hsa-miR-1 and long noncoding RNA MALAT1 promotes triple-negative breast cancer development. Tumor Biol 37: 7383-7394. doi:10.1007/ s13277-015-4605-6

Kadota M, Sato M, Duncan B, Ooshima A, Yang HH, Diaz-Meyer N, Gere S, Kageyama S, Fukuoka J, Nagata T, et al. 2009. Identification of novel gene amplifications in breast cancer and coexistence of gene amplification with an activating mutation of PIK3CA. Cancer Res 69: 7357-7365. doi:10.1158/0008-5472 .CAN-09-0064

Kadota M, Yang HH, Gomez B, Sato M, Clifford RJ, Meerzaman D, Dunn BK, Wakefield LM, Lee MP. 2010. Delineating genetic alterations for tumor progression in the MCF10A series of breast cancer cell lines. PLoS One 5: e9201. doi:10.1371/journal.pone.0009201

Khan A, Giri S, Wang Y, Chakraborty A, Ghosh AK, Anantharaman A, Aggarwal V, Sathyan KM, Ha T, Prasanth KV, et al. 2015. BEND3 represses rDNA transcription by stabilizing a NoRC component via USP21 deubiquitinase. Proc Natl Acad Sci 112: 8338-8343. doi:10.1073/pnas.1424705112

Lei B, Zhang Y, Liu T, Li Y, Pang D. 2016. Sox9 upregulation in breast cancer is correlated with poor prognosis and the $\mathrm{CD}_{4} 4^{+}$/ CD24-/low phenotype. Int J Clin Exp Pathol 9: 7345-7351.

Leipoldt M, Erdel M, Bien-Willner G, Smyk M, Theurl M, Yatsenko S, Lupski JR, Lane AH, Shanske AL, Stankiewicz P, et al. 2007. Two novel translocation breakpoints upstream of SOX9 define borders of the proximal and distal breakpoint cluster region in campomelic dysplasia. Clin Genet 71: 67-75. doi:10.1111/j.1399-0004.2007 .00736.x

Li J, Han L, Roebuck P, Diao L, Liu L, Yuan Y, Weinstein JN, Liang H. 2015a. TANRIC: an interactive open platform to explore the function of IncRNAs in cancer. Cancer Res 75: 3728-3737. doi:10 .1158/0008-5472.CAN-15-0273

Li J-R, Sun C-H, Li W, Chao R-F, Huang C-C, Zhou XJ, Liu C-C. 2015b. Cancer RNA-Seq Nexus: a database of phenotype-specific transcriptome profiling in cancer cells. Nucleic Acids Res 44: D944D951.

Liu C-F, Lefebvre V. 2015. The transcription factors SOX9 and SOX5/ SOX6 cooperate genome-wide through super-enhancers to drive chondrogenesis. Nucleic Acids Res 43: 8183-8203. doi:10.1093/ nar/gkv688 
Livak KJ, Schmittgen TD. 2001. Analysis of relative gene expression data using real-time quantitative PCR and the $2-\Delta \Delta C T$ method. Methods 25: 402-408. doi:10.1006/meth.2001.1262

Lv M, Xu P, Wu Y, Huang L, Li W, Lv S, Wu X, Zeng X, Shen R, Jia X, et al. 2016. LncRNAs as new biomarkers to differentiate triple negative breast cancer from non-triple negative breast cancer. Oncotarget 7: 13047. doi:10.18632/oncotarget.7509

Matouk IJ, Raveh E, Abu-lail R, Mezan S, Gilon M, Gershtain E, Birman T, Gallula J, Schneider T, Barkali M, et al. 2014. Oncofetal H19 RNA promotes tumor metastasis. Biochim Biophys Acta 1843: 1414-1426. doi:10.1016/j.bbamcr.2014.03 .023

McKeen Polizzotti L, Oztan B, Bjornsson CS, Shubert KR, Yener B, Plopper GE. 2012. Novel image analysis approach quantifies morphological characteristics of 3D breast culture acini with varying metastatic potentials. J Biomed Biotechnol 2012: 102036. doi:10.1155/2012/102036

Mead TJ, Wang Q, Bhattaram P, Dy P, Afelik S, Jensen J, Lefebvre V. 2013. A far-upstream ( $-70 \mathrm{~kb})$ enhancer mediates Sox9 auto-regulation in somatic tissues during development and adult regeneration. Nucleic Acids Res 41: 4459-4469. doi:10.1093/nar/gkt140

Nguyen DX, Massagué J. 2007. Genetic determinants of cancer metastasis. Nat Rev Genet 8: 341. doi:10.1038/nrg2101

Ohba S, He X, Hojo H, McMahon AP. 2015. Distinct transcriptional programs underlie Sox9 regulation of the mammalian chondrocyte. Cell Rep 12: 229-243. doi:10.1016/j.celrep.2015.06.013

Pomp V, Leo C, Mauracher A, Korol D, Guo W, Varga Z. 2015. Differential expression of epithelial-mesenchymal transition and stem cell markers in intrinsic subtypes of breast cancer. Breast Cancer Res Treat 154: 45-55. doi:10.1007/s10549-015-3598-6

Prensner JR, Chinnaiyan AM. 2011. The emergence of IncRNAs in cancer biology. Cancer Discov 1: 391-407. doi:10.1158/21598290.CD-11-0209

Pritchett J, Athwal V, Roberts N, Hanley NA, Hanley KP. 2011. Understanding the role of SOX9 in acquired diseases: lessons from development. Trends Mol Med 17: 166-174. doi:10.1016/j .molmed.2010.12.001

Santner SJ, Dawson PJ, Tait L, Soule HD, Eliason J, Mohamed AN, Wolman SR, Heppner GH, Miller FR. 2001. Malignant MCF10CA1 cell lines derived from premalignant human breast epithelial MCF10AT cells. Breast Cancer Res Treat 65: 101-110. doi:10.1023/A:1006461422273

Schmitt AM, Chang HY. 2016. Long noncoding RNAs in cancer pathways. Cancer Cell 29: 452-463. doi:10.1016/j.ccell.2016.03.010

Shi Z, Chiang C-I, Labhart P, Zhao Y, Yang J, Mistretta T-A, Henning SJ, Maity SN, Mori-Akiyama Y. 2015. Context-specific role of SOX9 in NF-Y mediated gene regulation in colorectal cancer cells. Nucleic Acids Res 43: 6257-6269. doi:10.1093/nar/ gkv568

Siegel RL, Miller KD, Jemal A. 2016. Cancer statistics, 2016. CA Cancer J Clin 66: 7-30. doi:10.3322/caac.21332
Smyk M, Szafranski P, Startek M, Gambin A, Stankiewicz P. 2013. Chromosome conformation capture-on-chip analysis of longrange cis-interactions of the SOX9 promoter. Chromosome Res 21: 781-788. doi:10.1007/s10577-013-9386-4

Su X, Malouf GG, Chen Y, Zhang J, Yao H, Valero V, Weinstein JN, Spano JP, Meric-Bernstam F, Khayat D, et al. 2014. Comprehensive analysis of long non-coding RNAs in human breast cancer clinical subtypes. Oncotarget 5: 9864-9876. doi: 10.18632/oncotarget.2454

Tang B, Vu M, Booker T, Santner SJ, Miller FR, Anver MR, Wakefield LM. 2003. TGF- $\beta$ switches from tumor suppressor to prometastatic factor in a model of breast cancer progression. $J$ Clin Invest 112: 1116-1124. doi:10.1172/JCI200318899

Tang Z, Li C, Kang B, Gao G, Li C, Zhang Z. 2017. GEPIA: a web server for cancer and normal gene expression profiling and interactive analyses. Nucleic Acids Res 45: W98-W102. doi:10.1093/nar/ gkx247

Tripathi V, Song DY, Zong X, Shevtsov SP, Hearn S, Fu X-D, Dundr M, Prasanth KV. 2012. SRSF1 regulates the assembly of pre-mRNA processing factors in nuclear speckles. Mol Biol Cell 23: 3694 3706. doi:10.1091/mbc.e12-03-0206

Tripathi V, Shen Z, Chakraborty A, Giri S, Freier SM, Wu X, Zhang Y, Gorospe M, Prasanth SG, Lal A, et al. 2013. Long noncoding RNA MALAT1 controls cell cycle progression by regulating the expression of oncogenic transcription factor B-MYB. PLoS Genet 9: e1003368. doi:10.1371/journal.pgen.1003368

Ulitsky I, Bartel DP. 2013. lincRNAs: genomics, evolution, and mechanisms. Cell 154: 26-46. doi:10.1016/j.cell.2013.06.020

Van Grembergen O, Bizet M, Eric J, Calonne E, Putmans P, Brohée S, Olsen C, Guo M, Bontempi G, Sotiriou C, et al. 2016. Portraying breast cancers with long noncoding RNAs. Sci Adv 2: e1600220. doi:10.1126/sciadv. 1600220

Warburton AJ, Boone DN. 2017. Insights from global analyses of long noncoding RNAs in breast cancer. Curr Pathobiol Rep 5: 23-34. doi:10.1007/s40139-017-0122-1

Weigelt B, Baehner FL, Reis-Filho JS. 2010. The contribution of gene expression profiling to breast cancer classification, prognostication and prediction: a retrospective of the last decade. J Pathol 220: 263-280. doi:10.1002/path.2629

Xu S, Kong D, Chen Q, Ping Y, Pang D. 2017. Oncogenic long noncoding RNA landscape in breast cancer. Mol Cancer 16: 129. doi:10.1186/s12943-017-0696-6

Yan P, Luo S, Lu JY, Shen X. 2017. Cis- and trans-acting IncRNAs in pluripotency and reprogramming. Curr Opin Genet Dev 46: 170-178. doi:10.1016/j.gde.2017.07.009

Yao B, Wang Q, Liu CF, Bhattaram P, Li W, Mead TJ, Crish JF, Lefebvre V. 2015. The SOX9 upstream region prone to chromosomal aberrations causing campomelic dysplasia contains multiple cartilage enhancers. Nucleic Acids Res 43: 5394-5408. doi:10 $.1093 /$ nar/gkv426 

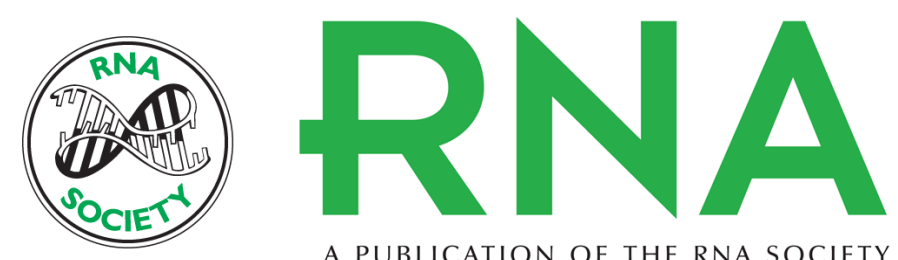

A PUBLICATION OF THE RNA SOCIETY

\section{LncRNA-mediated regulation of SOX9 expression in basal subtype breast cancer cells}

Aamira Tariq, Qinyu Hao, Qinyu Sun, et al.

RNA 2020 26: 175-185 originally published online November 5, 2019

Access the most recent version at doi:10.1261/rna.073254.119

\section{Supplemental http://rnajournal.cshlp.org/content/suppl/2019/11/05/rna.073254.119.DC1 \\ Material}

References This article cites 55 articles, 10 of which can be accessed free at: http://rnajournal.cshlp.org/content/26/2/175.full.html\#ref-list-1

Creative This article is distributed exclusively by the RNA Society for the first 12 months after the Commons full-issue publication date (see http://rnajournal.cshlp.org/site/misc/terms.xhtml). After 12

License months, it is available under a Creative Commons License (Attribution-NonCommercial 4.0 International), as described at http://creativecommons.org/licenses/by-nc/4.0/.
Email Alerting Receive free email alerts when new articles cite this article - sign up in the box at the Service top right corner of the article or click here.

To subscribe to $R N A$ go to:

http://rnajournal.cshlp.org/subscriptions 